\section{The Relationship between Leisure Satisfaction and Life Satisfaction in Food and Beverage Establishments}

\author{
Volkan GENC (corresponding author) \\ Batman University, Turkey \\ E-mail: volkangnc@yahoo.com \\ Seray GULERTEKIN GENC \\ Batman University, Turkey \\ E-mail: seraygulertekin@gmail.com
}

Received: November 28, 2016 Accepted: December 31, 2016 Published: January 4, 2017

doi: $10.5296 /$ jsss.v4i1.10369

URL: http://dx.doi.org/10.5296/jsss.v4i1.10369

\begin{abstract}
The aim of this study is to examine the relationship between the life satisfaction and leisure satisfaction of employees working in food and beverage establishments. The study was carried out in fine-dining restaurants in Eskisehir, Turkey, and adopted a quantitative paradigm. Eleven food and beverage establishments agreed to participate in the research, and a survey was administered to their employees. The data were obtained using the survey technique, and scales whose validity and reliability have been tested in earlier studies. A cluster sampling method was used, and a group of 156 people participated in the research. The research data were collected between March and June 2014. The results-identified a positive relationship between the leisure satisfaction and life satisfaction of employees working in food and beverage establishments. In addition, no significant differences in leisure satisfaction and life satisfaction were detected according to establishment type or gender. In line with the gained results, some suggestions were made for the executives and researchers of food and beverage establishments.
\end{abstract}

Keywords: Leisure satisfaction, Life satisfaction, Food and beverage establishments

\section{Introduction}

People's perspectives life, their attitudes and perceptions have become increasingly important 
in recent years. Both the popularization of tourism activities and the phenomenon of "eating out", which have gathered momentum alongside the process of industrialization, have boosted the importance of food and beverage services, especially since the second half of the last century (Kocak, 2012). The execution of services in these establishments and the satisfaction of customers largely depend on the self-devotion of their employees. The psychological states of employees, including their feelings, perceptions, and happiness have become an indispensable component of customer satisfaction (Genc, 2013).

Employees' performances in food and beverage establishments may also affect their perspectives on life. Job satisfaction, including the pleasure taken from the job itself and in their lives, has a positive effect on both mental and physical health, as well as life satisfaction (Orucu \& Esenkal, 2005). Thus life satisfaction, defined as the cognitive perceptions and assessments of life in general, has become important for organizations (Yetim, 1991). Riddick (1986) indicated that it is possible to explain the life satisfaction through economic, family, health and work-related factors, alongside leisure satisfaction. In this context, the very concept of leisure time and the satisfaction obtained from activities carried out during leisure time are becoming increasingly important (Gokce \& Orhan, 2011).

Leisure satisfaction creates positive feelings as individuals' needs are met through participation in leisure time activities, enabling individuals to acquire new skills as their health, social, cultural, sporting and artistic expectations of the events attended are met (Stenseng \& Phelps, 2013; Ardahan \& Yerlisu Lapa, 2010).

It is likely that life satisfaction is closely related to levels of participation, individuals' organization of their social lives, age, gender, working status, educational level, income level, health status, marital status and family life (Sener, Tersioglu, \& Karabulut, 2007). In addition, life satisfaction is described as the emotional response of the employee to life, which is defined as the time spent outside the workplace, leisure time and other non-business time (Rodriguez, Latkova, \& Sun, 2008). It is therefore conceivable to declare that one of the factors affecting a person's life satisfaction is their leisure satisfaction. The more employees are satisfied with their leisure time, the higher their general life satisfaction will be. As the performances of employees in labor-intensive sectors, such as in restaurants, significantly affect customer satisfaction, their aesthetic and emotional performance is also now considered important (Baum, 2006). The happier employees are as they prepare for a new day or a new week-except during busy working times- the more efficiently they work. This is directly related to leisure time satisfaction and life satisfaction. Thus, the question "Is there a relationship between the levels of leisure satisfaction and the levels of life satisfaction of employees in food and beverage establishments?" forms the problem of this research.

In the literature, there are studies that examine life satisfaction (Yetim, 1991; Selcukoglu 2001; Huebner 2004; Kwan 2008; Kong \& You, 2013) and leisure satisfaction (Karli, Polat, Uzum, \& Kocak, 2008; Ardahan \& Yerlisu Lapa, 2010; Celik, 2011; Chen, Li, \& Chen, 2013). However, research analyzing the relationship between the leisure satisfaction and life satisfaction of employees is limited.

The leisure satisfaction levels of employees serving in different types of food and beverage 
establishments may affect their life satisfaction in various ways. It is clear that employees' satisfaction levels from life have an effect on their ability to provide quality services to customers and thus on customer satisfaction. It is possible, therefore, to regard this case as a cycle.

This study aimed to determine the relationship between the levels of leisure satisfaction and the levels of life satisfaction of employees in food and beverage establishments. In recent years, both domestic and foreign investors have been purchasing major restaurants in Turkey whilst other important businesses have continued to provide services following mergers. At the same time, many restaurants are opening new branches through the system of Franchising. In the food and beverage sector, where competition is intense, customer satisfaction is heavily based on employee satisfaction. Therefore, this study will be carried out in food and beverage establishments.

As there are a limited number of studies in this subject area and those that have been examined do not focus on food and beverage establishments, this study is somewhat unique. Recognition of the relationship between the leisure satisfaction and life satisfaction of employees may help the managers of food and beverage establishments improve the management of their employees. This study also intends to contribute to the literature by focusing on the fact that customer satisfaction depends on employee satisfaction.

\section{Leisure Satisfaction}

A survey of the literature on leisure satisfaction reveals that different researchers have different perspectives, understandings, and evaluation of the issue. This is because leisure satisfaction is a relative concept. One of the first studies of leisure time, by De Grazia (1962, p. 11), defined leisure time as the opposite of the work time. Everybody may have free time but may not have leisure time. For instance, it may be both a hobby and a requirement for a person to shop. De Grazia (1962, p. 11) indicates that shopping that is done as a hobby is a free time activity. This is because the activity gives pleasure to the person. However, if shopping arises from necessity, it is then work that is performed during free time, and so cannot be considered free time. The researcher captures this difference by stating that "Free time and leisure time are two different concepts. Leisure time is a concept including the period of free time" (Torkildsen, 2005, p. 13; Gokce, 2008, p. 6; Gokce \& Orhan, 2011, p. 140; Sevil, 2012, p. 2).

It is possible, however, to find different definitions of leisure time. Leisure time (Mieczkowski, 1990; Ardahan \& Yerlisu Lapa, 2010) is the interval during which individual control is present without reliance on extraneous force, a feeling of happiness is evoked, no income is gained, and satisfactory experiences are gained. Ragheb and Tate (1993) point out that leisure time is time that does not include the time people use to work and meet their biological needs, and during which people are able to freely choose how to spend their time. In contrast, Sevil (2012) defines leisure time as the time used for sleep, necessary individual activities, and any remaining time spent not working. Although these definitions may differ, it is clear that people in modern societies require satisfaction in their lives outside the workplace, in order to relax and participate in other activities (Kilbas Koktas, 2004). Leisure 
time can therefore be expressed as the time taken for oneself.

Beard and Ragheb (1980) state that leisure satisfaction is the satisfaction obtained as a result of leisure time events that meet the preferences of individuals, and their reflections upon their feelings. A similar definition is provided by Seigenthaler (1997). It can be agreed that leisure time in general includes the contentment of the individual in their leisure time. Based on their aforementioned definition, Ardahan and Yerlisu Lapa (2010, p. 131) describe leisure satisfaction as the degree to which the health, social, cultural, sporting and artistic expectations of the individuals attending, either actively or passively, events are met, their subsequent feelings of health, pleasure, relaxation and happiness, as well as the acquisition of new skills, voluntarily and without dependence on extraneous force or with the expectation of monetary gain.

Several factors affect leisure time (e.g. gender, income, occupational differences, personality features etc.) and are connected to leisure time (job satisfaction, workload, quality of life, motivation, perceived freedom etc.), which are significant for both individuals and organizations. In the literature, various studies have attempted to identify these factors. One of the studies conducted in this area developed a scale with which leisure satisfaction can be measured (Beard \& Ragheb, 1980). This scale is used extensively today, including in our research, and consists of six sub-dimensions, namely education, psychology, physiology, relaxation, social, and aesthetic. Kabanoff (1982) then conducted a study of the impact of gender and occupational differences on leisure satisfaction. The study found that occupational differences have no impact on leisure satisfaction, and women took part in more entertainment-oriented leisure time activities than men. A similar study was conducted by Pearson (1998) on male full-time employees, in which it was found that workload negatively affects leisure satisfaction and job satisfaction. However, no differences could be found between white collar and blue collar workers regarding job satisfaction and leisure satisfaction. Similarly, Pearson (2008) explored the leisure satisfaction of full-time female employees. This study also found that workload has a negative effects on leisure satisfaction, whilst additionally demonstrating that there is a positive relationship between leisure satisfaction and job satisfaction and employees' psychological health. A similar study was carried out by Ardahan and Yerlisu Lapa (2010), examined university students' levels of leisure satisfaction according to gender and income. The study found that there were no differences in terms of gender but that income did have an effect on leisure satisfaction. Another study, however, demonstrated that, compared to male participants, female participants experience a greater sense of relaxation during their leisure time activities (Karli et al., 2008). This suggests that, in this context, there may be differences in leisure satisfaction according to gender.

Three types of models have been proposed to understand how job satisfaction and leisure satisfaction interact. According to the spillover model, if satisfaction in one field increases, satisfaction in other fields will also increase. According to the compensation model, however, a contradiction defines the job and leisure time. The relationship flows in the same direction (e.g. as leisure satisfaction increases, the individual's job satisfaction or his search for satisfaction will also increase) in terms of the amount of satisfaction experienced in both 
fields. Similarly when employees are satisfied in one field, they become more interested in other fields. Finally, in the segmentation model, it is claimed that these two areas of life are completely independent from one another; there is no relationship between them (Sumer and Knight, 2001). It can therefore be said that the above models would predict different levels of satisfaction among employees working in food and beverage establishments.

The relationship between leisure satisfaction and personality characteristics has also generated interest in the academic world. In a study by $\mathrm{Lu}$ and $\mathrm{Hu}$ (2005), a significant relationship was found between having an extrovert personality type and participating in leisure activities. The extrovert personality type was also found to be an indicator of happiness and leisure satisfaction, unlike the neurotic (frustrated) personality type. In a similar manner, Lu and Kao (2009) determined that extroverted and excitable people participate in more leisure time activities, and experience greater leisure satisfaction. Stenseng and Phelps (2013) examined the relationship between passion and leisure satisfaction. They found that there are two types of passions (harmonious and obsessive), and that life satisfaction is affected positively by harmonious passion. In contrast, it was shown that the leisure satisfaction of individuals with obsessive passions is affected negatively by their passions. The study suggests, therefore, that the factor that moves people to participate in leisure activities is motivation. On the other hand, Lloyd and Auld (2002) studied the role of leisure time in determining quality of life and found, that the most important indicator of quality of life is the satisfaction derived from private leisure time. Importantly, quality of life is not affected by the individual's location. Moreover, the study conclude that leisure satisfaction is high among those who participate in leisure activities and gain psychological benefits from such activities; this situation also positively affects life satisfaction. Thus, leisure satisfaction influences life satisfaction and quality of life. Indeed, it could be argued that leisure satisfaction is one dimension of satisfaction that is included in life satisfaction and social satisfaction (Ardahan \& Yerlisu Lapa, 2010). In a study on food and beverage establishments, Kodas, Kodas and Arica (2015) discovered that there is a positive relationship between leisure satisfaction and the perceived freedom of employees. Perceived freedom can be defined as the individual's sense of their own freedom when considering their place in their environment.

\section{Life Satisfaction}

Achieving happiness is a common goals for many people. The concept of happiness has been approached with questions such as 'how can people be happy?', 'what does happiness mean?', and 'what factors influence happiness?'; indeed how happiness can be sought remains an important question that has not lost its topicality (Civitci, 2012). Life satisfaction refers to the state of feeling well, and includes feelings of happiness and motivation in one's life in general.

The concept of life satisfaction was initially proposed by Neugart, Havighurst and Tobin (1961). Life satisfaction is neither limited to a field nor does it depend on just one theory, but has an interdisciplinary nature. The main theories that relate to life satisfaction in terms of individual aspects can be classified as follows: bottom-up and top-down theories, affective, 
cognitive, and unified theories, outcome and process theories, and requirement theories. Cognitive theories are often used in research as they generate more consistent results, thus improving their validity and reliability (Larsen, Diener, \& Emmons, 1985; Diener, Emmons, Larsen, \& Griffin, 1985). According to cognitive theory, life satisfaction is described as "a comparison of an individual's life in accordance with the criteria that he previously had set on his own" (Diener et al., 1985, p. 71). The first study of life satisfaction carried out in the national literature was by Yetim (1991). Yetim (1991, p. 113) defined life satisfaction as "a cognitive judgment of the individual including overall assessments on his life". In other words, it is a state or the result of a comparison between what the person wishes to have and what the person actually possesses. If a person states that he is satisfied with his life, it can be said that he mostly experiences positive feelings (Diener et al., 1985). Life satisfaction is considered to be a fundamental element of comprehensive happiness. The life satisfaction of employees may be affected by several factors, both inside and outside the organization. In a study by Keser (2005), the relationship between job satisfaction and life satisfaction was examined and it was determined that if employees experience feelings of job satisfaction, their life satisfaction will also be high. In a similar way, Seker and Zirhlioglu (2009) demonstrated that participants whose life satisfaction is high feel less emotional exhaustion and depersonalization, and have a higher sense of personal accomplishment compared to those whose life satisfaction is low. The participants whose job satisfaction was high, on the other hand, also had high levels of life satisfaction. Bedeian, Burke and Molffett (1988), O'Driscoll, Ilgen and Hildreth (1992), and Yigit, Dilmac and Deniz (2011) found similar results in their research. It can be asserted, therefore, based on the research mentioned above, that if employees experience job satisfaction, they are more likely to experience life satisfaction. Indeed, the job satisfaction experienced by employees will also affect their leisure time satisfaction. Therefore, it is clear that life satisfaction is related to both job satisfaction and leisure satisfaction.

The literature review reveals that there are many studies in the tourism sector about life satisfaction. Yilmaz, Keser and Yorgun (2010) conducted research in order to determine the job and life satisfaction of union member employees working in accommodation establishments, and found a relationship between job satisfaction and life satisfaction. Additionally, Kale's (2013) study found that employees in accommodation establishments who care about their success and their careers believe strongly that they will achieve their goals, and those that experience high life satisfaction have significantly higher levels of job performance.

In another study, Nawijn and Veenhoven (2011) stated that happiness is the most important factor affecting life satisfaction. They stated that happiness is particularly influenced by the level of satisfaction derived from the carrying out of one's activities. It can therefore be said that the leisure satisfaction of employees affects their levels of life satisfaction.

The relationship between leisure satisfaction and life satisfaction is based on two theories; needs and activity. Activity theory refers to one's participation in activities, which affects the frequency with which activities are participated in as well as life satisfaction. The more frequently individuals participate in leisure activities, the higher their degree of life 
satisfaction will be (Lemon, Bengtson, \& Peteron, 1972). The theory of needs divides needs into two types; basic physical and psychological needs. The health and welfare of individuals improve as these two needs are met. If they are not met, the individual's health condition declines and can even lead to ill health (Ryan \& Deci, 2000). Both theories demonstrate that leisure satisfaction enhances life satisfaction.

\section{Leisure Satisfaction and Life Satisfaction in Food and Beverage Establisments}

Employees play a significant role in the survival of food and beverage establishments and in providing a competitive advantage in an intensely competitive environment. Indeed, it is possible to say that employees are the most valuable resource in food and beverage establishments (Akoglan Kozak, 2004). As the thoughts and feelings of each employee in the food and beverage company may change during the working day, it is possible that his thoughts will not be in line with the services being provided. Thus, customer satisfaction and the company's success depend on the employee's happiness. Indeed, it is important to remember that each employee needs to have a specific time in which personal difficulties can be dealt with and in which they can engage in willingly chosen leisure activities. In restaurants, which are labor-intensive businesses, customer satisfaction, the sustainability of the business, and increasing business profitability are accepted as the main factors. Today, a significant proportion of consumers visit restaurants to enjoy a pleasant dining experience. To ensure consumer satisfaction, employees' soft skills (both aesthetic and emotional) are important as well as the happiness of employees in the workplace (Baum, 2006). Having employees who enjoy life and achieve the maximum level of satisfaction during their leisure time is important for the performance of the business. In addition, it is essential that the relationship between employees' leisure time satisfaction and their life satisfaction be understood.

Some studies have examined the relationship between leisure satisfaction and life satisfaction. Brown and Frankel (1993) audited the relationship between leisure satisfaction and life satisfaction, and suggested that women experience higher levels of leisure satisfaction than men. In addition, they showed that one of the major factors that increases life satisfaction is participation in leisure time activities. On the other hand, a study by Gokce (2008) found no significant relationship between leisure satisfaction and life satisfaction. In recent years, there has been an increase in research being conducted in this area due to the increasing importance given to leisure satisfaction. One such study was conducted by Yerlisu Lapa (2013), who determined that there is a positive relationship between life satisfaction and leisure satisfaction. Similar results were found by Kucuk Kilic, Lakot, Gurbuz and Oncu (2013). In another study, Sop (2014) found a positive relationship between job satisfaction and control over one's job, and life satisfaction, and a negative relationship between job satisfaction and job-leisure time conflict. In this context, therefore, it can be posited that if employees in food and beverage establishments experience high levels of leisure satisfaction, this will be reflected in their levels of life satisfaction and in their performance in the workplace.

\section{Research Model and Hypotheses}

The review model used in this research is of a descriptive nature. Review model aim to 
exactly set out the current situation and conditions. The cases provided are usually set in the natural environment. In such research, setting the variables - both experimentally and physically - and checking whether or not events occur are not in question (Guris \& Astar, 2014). This research aimed to identify the relationship between the levels of leisure satisfaction and levels of life satisfaction of the employees in the sample. The research has a descriptive nature as the determinations of these levels of satisfaction are based on the views of the participants. This research aimed to identify the relationship between the levels of leisure satisfaction and levels of life satisfaction of the employees in the sample. Going beyond this, levels of leisure time satisfaction and life satisfaction were investigated according to gender, restaurant classification, and working hours. The research model is as follows.

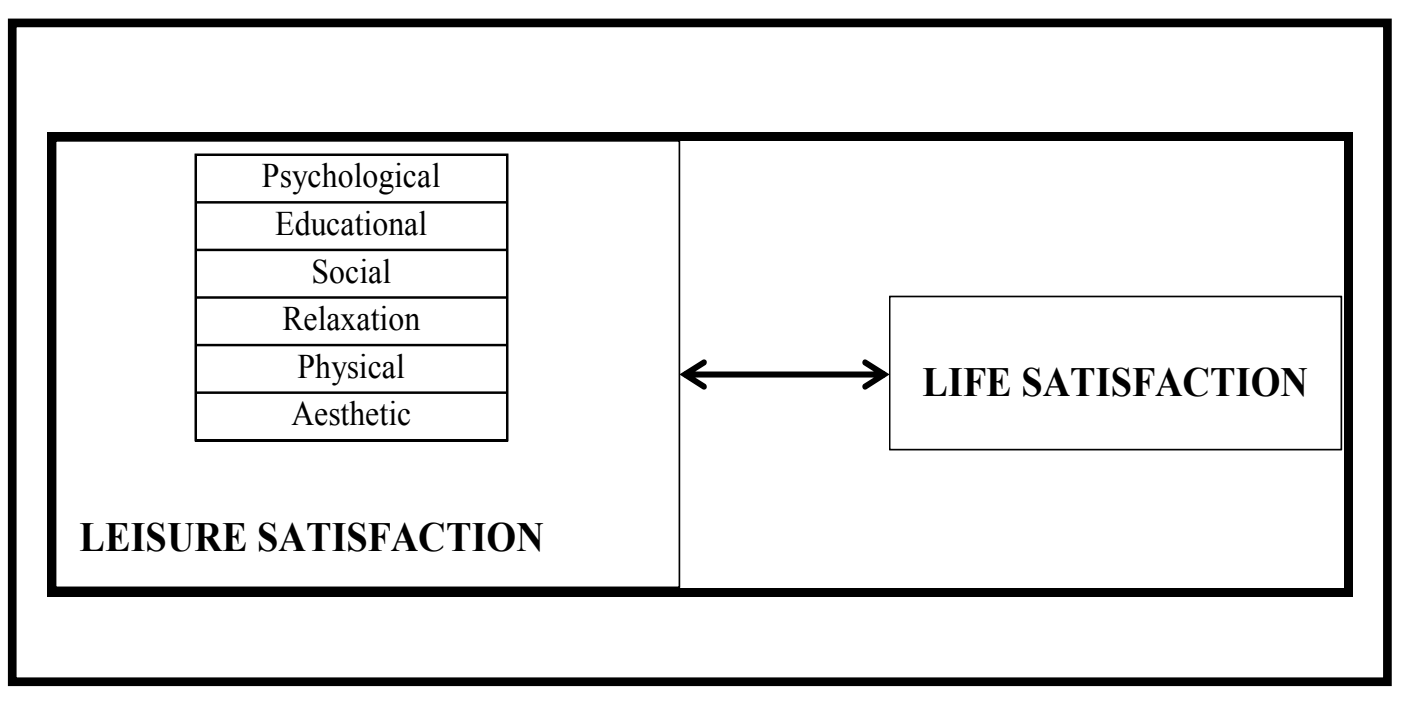

\subsection{Research Hypothesis}

The hypotheses to be tested in the study are:

Hypothesis 1: There is a significant relationship between food and beverage establishment employees' levels of life satisfaction and levels of leisure satisfaction.

Hypothesis 2: Employees of food and beverage establishments experience different levels of leisure satisfaction depending on the type of establishment they work in.

Hypothesis 3: Employees of food and beverage establishments experience different levels of life satisfaction depending on the type of establishment they work in.

\subsection{Method}

This study aims to determine the relationship between the levels of leisure satisfaction and life satisfaction of employees working in food and beverage establishments in Eskisehir. The population in this research consists of employees working in fine dining restaurants in Eskisehir, Turkey.

Fine dining restaurants in Turkey are either Ministry-certified or are privately-run restaurants. 


\section{Mll Macrothink}

Journal of Social Science Studies

ISSN 2329-9150

2017, Vol. 4, No. 1

The operating hours of these enterprises vary. By Turkish law, an employee's average working day is eight hours. Some businesses, however, have longer working hours but do not pay additional fees. This means that employees in those establishments have less leisure time, which could affect their levels of satisfaction.

In recent years Eskisehir has experienced a significant development in culture tourism, business tourism and spa tourism in Turkey. At the same time Eskisehir is an important destination of Turkey in terms of socio-cultural (Evren ve Kozak, 2012). Due to these developments Eskisehir was preferred in this study.

A cluster sampling method was used in this study. Here, the sampling group is selected based on a homogeneous structure formed by certain common features (Kozak, 2014). The food and beverage establishments in Eskisehir were divided into clusters according to classifications set by the government. There are 21 fine dining restaurants in Eskisehir; $151 \mathrm{st}$ class restaurants and six private facilities. Employees in these food and beverage establishments form the sample of this study.

According to the assumptions of parametric hypothesis testing, data should be equally spaced or proportional, it must conform to the normal distribution, and group variances should be equal (Kalayci, 2008). The basic data in this study was obtained using an interval scale (a 5-point attitude scale). The kurtosis and skewness values of the data are around -1.96 and +1.96; conforming to normal distribution. It can be said that the differences between the factors are equal. Therefore, the data gained in this research included information about the features covered in the questions and were subjected to parametric tests.

This study utilized the following data collection tools: a Satisfaction with Life Scale, a Leisure Satisfaction Scale, and some demographic questions. The Satisfaction with Life Scale was developed by Diener et al. (1985) in order to determine the life satisfaction of employees. This scale was then adapted into Turkish by Yetim (1991) and consists of five items. The items on the scale are graded on a 7-point Likert scale as follows: 7 - Strongly agree, 6 Agree, 5 - Slightly agree, 4 - Neither agree nor disagree, 3 - Slightly disagree, 2 - Disagree, 1 - Strongly disagree.

The long form of the Leisure Satisfaction Scale was developed by Beard and Ragheb (1980) but was then shortened in 2002 by Idyll Arbor Inc., who reduced it to 24 items. Permission to use the scale was obtained from Idyll Arbor Inc. The validity and reliability processes of the scale were carried out by Gokce and Orhan (2011) and were adapted into Turkish. The scale is comprised of six sub-factors (psychological, educational, social, relaxation, physical and aesthetic). The items on the scale are graded on a 5-point scale as follows: 1 - Not at all true, 2 - Rarely true, 3 - Sometimes true, 4 - Often true, 5 - Almost always true.

Mean and standard deviation values were calculated in order to describe the views of participants in terms of leisure satisfaction and life satisfaction, and a Pearson correlation analysis was performed in order to determine the relationship between leisure satisfaction and life satisfaction. In addition, a variance analysis and t-test were also conducted, while a Cronbach's alpha coefficient was calculated in order to test the reliability of leisure 


\section{Macrothink}

satisfaction and life satisfaction.

\section{Results}

To determine the demographic characteristics of the employees involved in this research, some questions were asked about the participants' gender, age, marital and educational status, term of employment in the industry, income status, position in the company, and the length of their work days. The findings are shown in Table 1 in the form of statistics.

Table 1. Distribution of participants by demographic characteristics

\begin{tabular}{|c|c|c|c|c|c|}
\hline Gender & Frequency & $\begin{array}{l}\text { Percentage } \\
(\%)\end{array}$ & Marital Status & Frequency & $\begin{array}{l}\text { Percentage } \\
(\%)\end{array}$ \\
\hline Female & 45 & 28.8 & Married & 68 & 43.6 \\
\hline Male & 111 & 71.2 & Single & 88 & 56.4 \\
\hline Total & 156 & 100.0 & Total & 156 & 100.0 \\
\hline Age Range & Frequency & $\begin{array}{l}\text { Percentage } \\
(\%)\end{array}$ & $\begin{array}{l}\text { Educational } \\
\text { Status } \\
\end{array}$ & Frequency & $\begin{array}{l}\text { Percentage } \\
(\%)\end{array}$ \\
\hline $18-22$ & 32 & 20.5 & $\begin{array}{l}\text { Primary } \\
\text { Education }\end{array}$ & 12 & 7.7 \\
\hline $23-27$ & 41 & 26.3 & Secondary & 69 & 44.2 \\
\hline $28-32$ & 50 & 32.1 & $\begin{array}{l}\text { Associate } \\
\text { Degree }\end{array}$ & 43 & 27.6 \\
\hline $33-37$ & 18 & 11.5 & undergraduate & 27 & 17.3 \\
\hline 38 and more & 15 & 9.6 & Postgraduate & 5 & 3.2 \\
\hline Total & 156 & 100.0 & Total & 156 & 100.0 \\
\hline $\begin{array}{l}\text { Daily Working } \\
\text { Period in the } \\
\text { Establishment }\end{array}$ & Frequency & $\begin{array}{l}\text { Percentage } \\
(\%)\end{array}$ & Income Status & Frequency & $\begin{array}{l}\text { Percentage } \\
(\%)\end{array}$ \\
\hline 8 hours and less & 38 & 24.4 & $350 \$$ and less & 44 & 28.2 \\
\hline 9-11 hours & 83 & 53.2 & $351 \$-650 \$$ & 79 & 50.6 \\
\hline 12 and more & 35 & 22.4 & $651 \$-950 \$$ & 17 & 10.9 \\
\hline \multirow[t]{2}{*}{ Total } & 156 & 100.0 & $951 \$$ and more & 16 & 10.3 \\
\hline & & & Total & 156 & 100.0 \\
\hline
\end{tabular}

While the majority (71.2\%) of the employees in the sample were male, the number of single employees was (56.4\%) higher than the married group. Most of the employees $(78.9 \%)$ were in the 18-32 age range, suggesting that food and beverage establishments are more likely to employ young people. The number of employees with a university degree level was relatively low, which may suggest that there is a shortage of qualified staff in this sector. In terms of the income status of the employees, the number of employees earning either $\$ 350$ or less or between \$351-650 reveals the state of the sector in terms of income levels. Additionally, 
surveying the length of the employees' work days reveals that $76 \%$ of the employees in the sample work approximately 9 hours or more. The working week is therefore at least 54 hours per week. This shows that the amount of leisure time enjoyed by employees' very low.

Next, a reliability analysis of the items in the scale (as seen in Table 2) was carried out, the arithmetic mean and standard deviation were calculated, and skewness and kurtosis values were examined. Kalayci (2008) indicates that if the scale is ' $0.60 \leq \alpha<0.80$ ', it is reliable, depending on Cronbach's alpha coefficient, and if the scale is ' $0.80 \leq \alpha<1.00$ ', it is highly reliable. The reliability analysis revealed that all of the dimensions are highly reliable. Following this, the study determined whether the data set provides multivariate normal distribution. In order to provide multivariate normality in the test/scale items, the skewness and kurtosis values of the variables should be between \pm 2 (Akbulut, 2010). As can be seen in Table 2, the skewness and kurtosis values for both life satisfaction and leisure satisfaction are between \pm 2 . Besides this, the equality of the group variances was examined by the Levene test. Thus, it was decided that parametric methods would be used, after it was determined that it is in accordance with normal distribution at a 0.05 significance level and that the group variances are equal.

Table 2. Reliability and central measurement values

\begin{tabular}{llllllll}
\hline & $\begin{array}{l}\text { Item } \\
\text { number }\end{array}$ & $\mathbf{N}$ & $\begin{array}{l}\text { Reliability } \\
\text { (Cronbach's } \\
\text { Alpha) }\end{array}$ & Mean & $\begin{array}{l}\text { Standard } \\
\text { Deviation }\end{array}$ & Skewness & Kurtosis \\
\hline $\begin{array}{l}\text { Life } \\
\text { Satisfaction }\end{array}$ & 5 & 156 & .922 & 3.6821 & 1.53108 & -.005 & -1.252 \\
\hline $\begin{array}{l}\text { Leisure } \\
\text { Satisfaction }\end{array}$ & 24 & 156 & .932 & 3.4554 & .78171 & -.692 & -.391 \\
\hline Psychological & 4 & 156 & .866 & 3.2724 & 1.08523 & -.384 & -1.153 \\
\hline Educational & 4 & 156 & .865 & 3.3654 & 1.07628 & -.369 & -1.075 \\
\hline Social & 4 & 156 & .859 & 3.5064 & 1.08023 & -.844 & -.505 \\
\hline Relaxation & 4 & 156 & .894 & 3.8365 & 1.04328 & -1.112 & .290 \\
\hline Physical & 4 & 156 & .874 & 3.0609 & 1.12356 & -.081 & -1.252 \\
\hline Aesthetic & 4 & 156 & .871 & 3.6907 & .7616 & -.766 & .0270 \\
\hline
\end{tabular}

The arithmetic means in Table 2 reveal that the life satisfaction value (3.68) scores are in the 1-7 range, which is below the median (four points). This suggests that the employees in the sample have negative views about their life satisfaction. The arithmetic means of leisure satisfaction, on the other hand, is 3.46; this is over three points, which is the middle value in the 1-5 range. This shows that the employees in the sample have positive views about their leisure satisfaction. The arithmetic means in relation to the leisure satisfaction dimensions were determined to be close to each other, and the most positive opinion was calculated in the 'relaxation' factor. This finding demonstrates that employees working in the food and 


\section{Macrothink}

Journal of Social Science Studies

ISSN 2329-9150

2017, Vol. 4, No. 1

beverage establishments in Eskisehir regard the 'relaxation' factor as the most important when it comes to leisure satisfaction. However, 'social', 'aesthetic', 'educational' and 'psychological' factors were found to be positive, while the 'physical' factor was found to be a negative factor with the lowest mean.

In the study, a confirmatory factor analysis (CFA) for leisure satisfaction was conducted as such an analysis can provide researchers with the opportunity to test the proposed model or theory (Tabachnick \& Fidell, 2001). The purpose of the CFA is to determine the success of the fit between the model and the sample. As a result of the CFA, six factor structures of leisure satisfaction were confirmed. The accepted value ranges of the conformity index and the relevant criteria are presented in Table 3.

Table 3. Confirmatory factor analysis of goodness of fit index

\begin{tabular}{|c|c|c|c|}
\hline Cohesion Criterion & $\begin{array}{l}\text { Obtained } \\
\text { Criterion }\end{array}$ & Cohesion & Acceptable Cohesion \\
\hline$X^{2} / s d$ & 2.121 & & $2 \leq \chi 2 / s d \leq 3$ \\
\hline CFI (Comparative Fit Index) & .900 & & $.90 \leq C F I \leq .95$ \\
\hline GFI (Goodness of Fit Index) & .802 & & $.90 \leq G F I \leq 95$ \\
\hline NFI (Normed Fit Index) & .829 & & $.90 \leq N F I \leq .95$ \\
\hline $\begin{array}{l}\text { RMSEA (Root Mean Square Error of } \\
\text { Approximation) }\end{array}$ & .085 & & $0.05<R M S E A<0,10$ \\
\hline PGFI (Parsimonious goodness-of-fit index) & .623 & & $\begin{array}{l}\text { Threshold limit value } \\
0.50\end{array}$ \\
\hline
\end{tabular}

The Pearson correlation analysis, which was applied to discover the relationship between life satisfaction and leisure satisfaction, is shown in Table 4. The results show that the correlation coefficients between life satisfaction, dimensions of leisure, and dimensions of leisure satisfaction were positive and significant (important) $(\mathrm{p}<0.01 ; \mathrm{p}<0.05)$. 
Table 4. Correlations between dimensions

\begin{tabular}{|c|c|c|c|c|c|c|c|}
\hline & $\begin{array}{l}\text { Life } \\
\text { Satisfaction }\end{array}$ & Psychological & Educational & Social & Relaxation & Physical & Aesthetic \\
\hline $\begin{array}{l}\text { Life } \\
\text { Satisfaction }\end{array}$ & 1 & & & & & & \\
\hline Psychological & $.433^{* *}$ & 1 & & & & & \\
\hline Educational & $.390^{* *}$ & $.711^{* *}$ & 1 & & & & \\
\hline Social & $.324^{* *}$ & $.576^{* *}$ & $.602^{* *}$ & 1 & & & \\
\hline Relaxation & $.357^{* *}$ & $.502^{* *}$ & $.505^{* *}$ & $.545^{* *}$ & 1 & & \\
\hline Physical & $.397^{* *}$ & $.415^{* *}$ & $.314^{* *}$ & $.221^{*}$ & $.335^{* *}$ & 1 & \\
\hline Aesthetic & $.186^{*}$ & $.413^{* *}$ & $.380^{* *}$ & $.287^{* *}$ & $.401^{* *}$ & $.252^{*}$ & 1 \\
\hline
\end{tabular}

$* \mathrm{p}<0.05 . \quad * * \mathrm{p}<0.01$.

The results obtained from the correlation analysis support the hypothesis that 'There is a significant relationship between the life satisfaction and leisure satisfaction of the employees.' Studying the results in Table 5 reveals that there was no difference in the life satisfaction and leisure satisfaction dimensions at the 0.05 significance level. These results suggest, therefore, that there is no difference between female employees and male employees in food and beverage establishments in terms of their leisure satisfaction dimensions and life satisfaction dimensions.

Table 5. t-test analysis table by gender

\begin{tabular}{|c|c|c|c|c|c|c|c|}
\hline Dimension & Gender & $\mathbf{N}$ & Mean. & s.s. & s.d. & $\mathbf{t}$ & $\mathbf{p}$ \\
\hline \multirow{2}{*}{$\begin{array}{l}\text { Life } \\
\text { Satisfaction }\end{array}$} & Female & 45 & 3.9511 & 1.374 & 154 & 1.402 & .067 \\
\hline & Male & 111 & 3.5730 & 1.583 & & & \\
\hline \multirow{2}{*}{ Psychological } & Female & 45 & 3.3500 & 1.054 & 154 & .567 & .588 \\
\hline & Male & 111 & 3.2410 & 1.100 & & & \\
\hline \multirow{2}{*}{ Educational } & Female & 45 & 3.3889 & 1.106 & 154 & .173 & .613 \\
\hline & Male & 111 & 3.3559 & 1.069 & & & \\
\hline \multirow{2}{*}{ Social } & Female & 45 & 3.3554 & 1.058 & 154 & .279 & .956 \\
\hline & Male & 111 & 3.4910 & 1.093 & & & \\
\hline \multirow{2}{*}{ Relaxation } & Female & 45 & 4.0722 & 0.883 & 154 & 1.810 & .079 \\
\hline & Male & 111 & 3.7410 & 1.091 & & & \\
\hline \multirow{2}{*}{ Physical } & Female & 45 & 3.0778 & 1.104 & 154 & .119 & .632 \\
\hline & Male & 111 & 3.0541 & 1.136 & & & \\
\hline \multirow{2}{*}{ Aesthetic } & Female & 45 & 3.7556 & 0.960 & 154 & .541 & .759 \\
\hline & Male & 111 & 3.6644 & 0.951 & & & \\
\hline
\end{tabular}

${ }^{*} \mathrm{p}<0.05$ 
The results in Table 6 show that no significant difference was found between the life and leisure satisfaction levels of different categories of employees in food and beverage establishments. It can therefore be inferred that there is no significant difference between employees working in 1st class restaurants and those that work in food and beverage establishments that hold private operation license, in terms of their life satisfaction and leisure satisfaction.

Table 6. t-test analysis table by classification of establishments

\begin{tabular}{|c|c|c|c|c|c|c|c|}
\hline Dimension & Classification & $\mathbf{N}$ & Mean. & s.s. & s.d. & $\mathbf{t}$ & $\mathbf{p}$ \\
\hline \multirow{2}{*}{ Life Satisfaction } & $1^{\text {st }}$ class & 89 & 4.023 & 1.439 & 154 & 3.301 & 0.553 \\
\hline & Private Facility & 67 & 3.230 & 1.543 & & & \\
\hline \multirow{2}{*}{ Psychological } & $1^{\text {st }}$ class & 89 & 3.489 & 1.018 & 154 & 2.939 & 0.133 \\
\hline & Private Facility & 67 & 2.985 & 1.112 & & & \\
\hline \multirow{2}{*}{ Educational } & $1^{\text {st }}$ class & 89 & 3.548 & 1.048 & 154 & 2.479 & 0.557 \\
\hline & Private Facility & 67 & 3.123 & 1.072 & & & \\
\hline \multirow{2}{*}{ Social } & $1^{\text {st }}$ class & 89 & 3.573 & 1.148 & 154 & .887 & 0.172 \\
\hline & Private Facility & 67 & 3.418 & 0.972 & & & \\
\hline \multirow{2}{*}{ Relaxation } & $1^{\text {st }}$ class & 89 & 3.947 & 0.972 & 154 & 1.526 & 0.193 \\
\hline & Private Facility & 67 & 3.690 & 1.122 & & & \\
\hline \multirow{2}{*}{ Physical } & $1^{\text {st }}$ class & 89 & 3.180 & 1.107 & 154 & 1.530 & 0.683 \\
\hline & Private Facility & 67 & 2.903 & 1.134 & & & \\
\hline \multirow{2}{*}{ Aesthetic } & $1^{\text {st }}$ class & 89 & 3.764 & 0.900 & 154 & 1.111 & 0.227 \\
\hline & Private Facility & 67 & 3.593 & 1.014 & & & \\
\hline
\end{tabular}

${ }^{*} \mathrm{p}<0.05$.

According to the results obtained from the t-test analysis, hypotheses 2 and 3, that employees in different types of food and beverage establishments experience different' levels of leisure satisfaction and life satisfaction,' are rejected.

The dimensions of life satisfaction and leisure satisfaction of employees were investigated using ANOVA to determine whether there are any significant differences according to the length of employees' work days. In addition, the Tukey test, which is one of the multiple comparison tests, was used to determine in which groups there were differences.

The length of employees' working days was one of the main determinants of the satisfaction levels obtained from leisure time. Employees in food and beverage establishments in Turkey face uncertainty in the number of hours they will work each week. This can affect employees' life satisfaction and leisure time satisfaction. A comparison of different employees can give us an idea of the importance of this issue. After analyzing the results of the ANOVA analysis in Table 7, we can say that there are significant differences between the life satisfaction of employees depending on the length of their working day. It is also clear that these differences 


\section{Al Macrothink}

reflect the point averages of the dimensions of life satisfaction. Similarly, the results reveal differences between employees' sub-dimensions of leisure time depending on the length of their working day.

The Tukey test was performed to discover which groups exhibit significant differences. In terms of life satisfaction, a significant difference was detected between employees that work 8 hours or less and those that work 12 hours or more; the former experience greater satisfaction than the latter. Under the psychology sub-dimension, significant differences were found between the ' 8 hours or less' group, the ' $9-11$ hours' group, and the ' 12 hours or more' group. Employees working 9-11 hours are more psychologically comfortable than those working 12 hours or more. A similar situation can be found in the social and aesthetic sub-groups. Finally, significant differences were identified in the relaxation and physical sub-groups, such as between those who work 9-11 hours and those who work 12 hours or more. A comparison between employees that work 12 hours or more and those that work 8 hours or less also reveal that the latter feel more comfortable in terms of educational, social and aesthetic aspects. This is because they can allocate more time to their education, socialization, and aesthetics. 
Table 7. ANOVA and Tukey Test table by daily working hours

\begin{tabular}{|c|c|c|c|c|c|c|c|c|c|}
\hline \multirow[t]{2}{*}{ Dimension } & \multirow[t]{2}{*}{$\begin{array}{l}\text { Working } \\
\text { Period }\end{array}$} & \multirow[t]{2}{*}{$\mathbf{N}$} & \multirow[t]{2}{*}{ Mean } & \multirow[t]{2}{*}{ s.s. } & \multirow[t]{2}{*}{$\mathbf{F}$} & \multirow[t]{2}{*}{$\mathbf{P}$} & \multicolumn{3}{|c|}{ Tukey Testi } \\
\hline & & & & & & & $8 \leq$ hours & 9-11 hours & $12 \geq$ hours \\
\hline \multirow{3}{*}{$\begin{array}{l}\text { Life } \\
\text { Satisfaction }\end{array}$} & $8 \leq$ hours & 38 & 4.20 & 1.51 & 5.784 & .004 & - & .477 & $1.177 *$ \\
\hline & 9-11 hours & 83 & 3.72 & 1.44 & & & -.477 & - & .700 \\
\hline & $12 \geq$ hours & 35 & 3.02 & 1.57 & & & $-1.177^{*}$ & -.700 & - \\
\hline \multirow{3}{*}{ Psychological } & $8 \leq$ hours & 38 & 3.57 & 1.10 & 3.300 & .000 & - & .129 & $1.00^{*}$ \\
\hline & 9-11 hours & 83 & 3.44 & 0.95 & & & -.129 & - & $.872 *$ \\
\hline & $12 \geq$ hours & 35 & 2.56 & 1.09 & & & $-1.00 *$ & $.872 *$ & - \\
\hline \multirow{3}{*}{ Educational } & $8 \leq$ hours & 38 & 3.66 & 1.01 & 2.101 & .000 & - & .149 & $.951 *$ \\
\hline & 9-11 hours & 83 & 3.51 & .96 & & & -.149 & - & $.802 *$ \\
\hline & $12 \geq$ hours & 35 & 2.71 & 1.16 & & & $-.951 *$ & $-.802 *$ & - \\
\hline \multirow{3}{*}{ Social } & $8 \leq$ hours & 38 & 3.65 & .90 & 1.813 & .011 & - & .010 & $.622 *$ \\
\hline & 9-11 hours & 83 & 3.64 & 1.04 & & & -.010 & - & $.613^{*}$ \\
\hline & $12 \geq$ hours & 35 & 3.03 & 1.22 & & & $-.622 *$ & $-.613 *$ & - \\
\hline \multirow{3}{*}{ Relaxation } & $8 \leq$ hours & 28 & 3.78 & 1.02 & 4.928 & .002 & - & -.286 & .440 \\
\hline & 9-11 hours & 83 & 4.07 & .84 & & & .286 & - & $.726^{*}$ \\
\hline & $12 \geq$ hours & 35 & 3.34 & 1.32 & & & -.440 & $-.726^{*}$ & - \\
\hline \multirow{3}{*}{ Physical } & $8 \leq$ hours & 38 & 3.23 & 1.12 & 1.00 & .351 & - & -.0360 & .266 \\
\hline & 9-11 hours & 83 & 3.07 & 1.05 & & & .360 & - & $.626^{*}$ \\
\hline & $12 \geq$ hours & 35 & 2.85 & 1.28 & & & -.266 & $-.626^{*}$ & - \\
\hline \multirow{3}{*}{ Aesthetic } & $8 \leq$ hours & 38 & 3.56 & .92 & 2.219 & .003 & - & -.033 & $.610^{*}$ \\
\hline & 9-11 hours & 83 & 3.92 & .79 & & & .033 & - & $.644^{*}$ \\
\hline & $12 \geq$ hours & 35 & 3.29 & 1.18 & & & $-.610^{*}$ & $-.644^{*}$ & - \\
\hline
\end{tabular}

$\mathrm{P}<0.05$.

\section{Conclusions and Recommendations}

This study examined employees working in the food and beverage sector, where human resources are an extremely important factor in business performance. A correlation analysis was used to determine whether there is a relationship between the leisure satisfaction and life satisfaction of employees in food and beverage establishments. The correlation coefficients between the leisure satisfaction levels and life satisfaction levels of employees in food and beverage establishments were found to be significant. It is therefore believed that there is a relationship between the leisure satisfaction levels and the life satisfaction levels of employees. In line with these findings, some studies (Brown \& Frankel, 1993; Rodriguez et al., 2008; Wang, Chen, Lin, \& Wang, 2008; Aghia 2013) found significant relationships between life satisfaction and leisure satisfaction. At the same time, these findings also support the spillover model. If employees' satisfaction in one area increases, this increases satisfaction in other areas. As Benjamin Franklin said, "time is cash"; to waste time is to 
waste money. People have taken this to mean that one must not waste time. Leisure time is often organized in a similar way to how work is organized; it is planned, calculated, partitionable, and it also requires effort (Urry, 2015, p. 18). Therefore, satisfaction with one's leisure time is related to satisfaction with life.

According to the results of the research, no significant difference was identified between male employees and female employees in the dimension of life satisfaction. This result is in line with other research (Hampton \& Marshall, 2000; Hintikka, 2001; Selcukoglu, 2001; Fugl Meyer, Melin, \& Fugl Meyer, 2002; Cetinkaya, 2004; Akandere, 2007; Kumartasli, 2010). Similarly, no significant difference was detected in leisure satisfaction according to employees' gender. This result is also supported by research conducted by Ardahan and Yerlisu Lapa (2010).

In this study, no difference was detected between the life satisfaction of employees working in 1st class restaurants, also known as fine dining restaurants, and those working in privately-run food and beverage establishments. This result differs significantly from research that was carried out by Turkay, Kaya and Birer (2013). It may be said that employees in the food and beverage industry have similar expectations.

It was found that the life satisfaction of employees who work 8 hours or less is higher than those who work 12 hours or more. Likewise, employees who work between 9 and 11 hours experience higher psychological, educational and social relaxation satisfaction compared to the ones who work 12 hours or more. Therefore, the more hours an employee works, the less satisfaction they are likely to obtain from their leisure time. It is also understood that the issue of working hours seems to be similar in both 1st class restaurants and privately-run restaurants.

It is believed that this study will contribute to the literature in this subject area as there is no similar research investigating working hours and life and leisure satisfaction.

It seems that the leisure satisfaction and life satisfaction levels of employees working in fine dining restaurants in Eskisehir are not at the desired level. However, the life satisfaction and leisure satisfaction of employees may increase if some improvements are made and some measures taken in the areas mentioned below.

- First, remuneration policies that apply to employees in food and beverage establishments should be revised. Wages must be organized in a fair manner depending on the economic conditions of the country and the conditions of the region in which the establishments are based. In addition, the insurance premiums of employees should be regularly and fully deposited, and when an employee is entitled to take his annual leave from work, the employee should be allowed to benefit from this right.

- Another remarkable point is that the working hours of employees working in food and beverage establishments are very long. If these establishments want to receive maximum efficiency from their employees, they must pay attention to their working hours and should not let them work more than 8 hours a day. If this is not possible, overtime pay must be provided. 


\section{Macrothink}

- Due to the intensity of the work in food and beverage establishments on weekends, employees are allowed to take days off during the week. This position often hampers employees' ability to spend time with partners, family, and friends. Employees should be allowed to take days off on alternate weekends, and days off during the week should be fixed. It should, after all, be remembered that customer satisfaction is achieved through employee satisfaction.

- The managers of food and beverage establishments should hold activities (staff nights, picnics, barbecues, etc.) during certain periods. Additionally, at certain times of the year, sports tournaments should be organized, and a team spirit within the establishment should be created through social activities.

- In terms of shedding light on future research, leisure time satisfaction can be examined within particular cultural contexts. The influence of culture on leisure time satisfaction may be examined.

This study is limited to employees working in fine dining restaurants in Eskisehir city center. In addition, if the study had used a larger sample of employees, it may have been able to provide more generalizable results. Nevertheless, leisure satisfaction is an issue that has not been studied very often either in the national or international literature. It is therefore suggested that leisure satisfaction should be investigated through the use of feeling-based variables.

\section{References}

Agyar, E. (2013). Contribution of perceived freedom and leisure satisfaction to life satisfaction in a sample of Turkish women, Social Indicators Research, 116(1), 1-15. https://doi.org/10.1007/s11205-013-0268-0

Akandere, M. (2007). Huzurevinde Kalan Yaslilarda Fiziksel Aktivitelerin Yasam Doyum Duzeylerine etkisi. [Title in English: The effect of physical activity to levels of life satisfaction on elderly people in the nursing home]. Selcuk Universitesi Sosyal Bilimler Enstitusu Dergisi, 18, 1-9.

Akoglan Kozak, M. (2004). Otel Isletmelerinde Insan Kaynaklarl Yonetimi. [Human Resources Management in Hotels Establishments]. Ankara: Detay Yayincilik.

Ardahan, F., \& Yerlisu Lapa, T. (2010). Universite Ogrencilerinin Serbest Tatmin Duzeylerinin Cinsiyete ve Gelire Gore Incelenmesi. [Title in English: An Examination of Leisure Satisfaction Level of University Students with regard to Gender and Income]. Hacettepe Journal of Sport Science, 21(4), 129-136.

Baum, T. (2006). Reflections on the Nature of Skills in the Experience Economy: Challenging Traditional Skills Models in Hospitality, Journal of Hospitality and Tourism Management, 13(2), 124-135. https://doi.org/10.1375/jhtm.13.2.124

Beard, J. G., \& Ragheb, M. G. (1980). Measuring Leisure Satisfaction, Journal of Leisure Research, 12, 20-33. 
Bedeian, A. G., Burke, B. G., \& Molffett, R. G. (1988). Outcomes of Work-Family Conflict Among Married Male and Female Professionals, Journal of Management, 14, 475-491. https://doi.org/10.1177/014920638801400310

Brown, B. A., \& Frankel, B. G. (1993). Activity through the years: Leisure, leisure satisfaction, and life satisfaction, Sociology of Sport Journal, 10, 1-17. https://doi.org/10.1123/ssj.10.1.1

Celik, G. (2011). Kamu Kuruluslarında Calısan Engelli Bireylerin Serbest Zaman Engellerinin ve Tatmin Duzeylerinin İncelenmesi (Antalya Merkez Ornegi). (Unpublished master's thesis). Akdeniz Universitesi, Antalya.

Cetinkaya, H. (2004). Beden imgesi, beden organlarından memnuniyet, benlik saygisı, yasam doyumu ve sosyal karsilastırma duzeyinin demografik degiskenlere gore farklılasmasi. (Unpublished master's thesis). Mersin Universitesi, Mersin.

Cevik, S., \& Akoglan Kozak, M. (2011, December). Degisim Yonetiminde Donusumcu Liderlik ve Hizmetkar Liderlik. 11. Ulusal Turizm Kongresi Bildiri Kitabl, 80-87, Kusadasi.

Chen, Y. C., Li, R. H., \& Chen, S. H. (2013). Relationships among Adolescents' Leisure Motivation, Leisure Involvement and Leisure Satisfaction: A Structural Equation Model, Social Indicators Research, 110(3), 1187-1199. https://doi.org/10.1007/s11205-011-9979-2

Civitci, A. (2012). Universite Ogrencilerinde Genel Yasam Doyumu ve Psikolojik İhtiyaclar Arasındaki İliskiler. [Title in English: The Relationships Between Global Life Satisfaction and Psychological Needs in University Students]. C. U. Sosyal Bilimler Enstitusu Dergisi, 21(2), 321-336.

De Grazia, S. (1962). Of time, work, and leisure. New York: Twentieth Century

Diener, E., Emmons, R. A., Larsen, R. J., \& Griffin, S. (1985). The satisfaction wiht life scale, Journal of Personality Assessment, $\quad 49(1), \quad$ 71-75. https://doi.org/10.1207/s15327752jpa4901_13

Evren, S., \& Kozak, N. (2012). Eskisehir'deki Cekici Faktorlerinin Gunubirlik Ziyaretcilerin Bakis Acisiyla Degerlendirilmesi, Anatolia: Turizm Arastirmalari Dergisi, 23(2), 220-232.

Fugl, Meyer, A. R., Melin, R., \& Fugl Meyer, K. S. (2002). Life satisfaction in 18- to 64-year-old swedes: In relation to gender, age, partner and immigrant status, Journal of Rehabilitation Medical, 34, 239-246. https://doi.org/10.1080/165019702760279242

Genc, V. (2013). Alanya'daki Turizm İsletmelerinde Calisanlarin Duygusal Emek ve Duygusal Zeka Duzeylerinin Is Tatminine Etkileri. (Unpublished master's thesis). Canakkale Onsekiz Mart Universitesi, Canakkale.

Gokce, H. (2008). Serbest Zaman Doyumunun Yasam Doyumu ve Sosyo- Demografik Degiskenlerle Iliskisinin Incelenmesi. (Unpublished master's thesis). Pamukkale Universitesi Saglik Bilimleri Enstitusu, Denizli.

Gokce, H., \& Orhan, K. (2011). Serbest Zaman Doyum Olceginin Turkce Gecerlilik 
Guvenirlik Calısmas1. [Title in English: Validity and Reliability Study of the Leisure Satisfaction Scale (LSS) into Turkish]. Hacettepe Journal of Sport Sciences, 22(4), 139-145.

Guris, S., \& Astar, M. (2014). Bilimsel Arastirmalarda SPSS ile Istatistik. [Title in English: By SPSS Statistics in Scientific Research]. Istanbul: Der Yayınları.

Hampton, N. Z., \& Marshall, A. (2000). Culture, gender, self-efficacy and life satisfaction: A comparison between Americans and Chinese people with spinal cord injuries, Journal of Rehabilitation, 66(3), 21-28.

Hintikka, J. (2001). Religious attendance and life satisfaction in the Finnish general population, Journal of Psychology and Theology, 29(2), 158-164.

Huebner, E. S. (2004). Research on Assesment of Life Satisfaction of Children and Adolescents, Social Indicators $\quad$ Research, $\quad 66, \quad 33$. https://doi.org/10.1023/B:SOCI.0000007497.57754.e3

Kabanoff, B. (1982). Occupational and sex differences in leisure needs and leisure satisfaction, Journal of Occupational Behaviour, 3, 233-245. https://doi.org/10.1002/job.4030030304

Kalayci, S. (2008). SPSS Uygulamalarl Cok Degiskenli Istatistik Teknikleri. [Title in English: SPSS Applied Multivariate Statistical Techniques]. Ankara: Asil Yayin Dagitim.

Kale, E. (2013). Konaklama İsletmelerinde Oz Uyumun İs Performansına Etkisi: Yasam Doyumunun Arac1 Rolu. [Title in English: The Effects of Self Concordance on Job Performance in Hospitality Companies: The Moderating Role of Life Satisfaction]. Yonetim Bilimleri Dergisi, 11, 117-133.

Karli, U., Polat, E., Uzum, H., \& Kocak, S. (2008, November). Universite Ogrencilerinin Serbest Zaman Tatmin Duzeyleri, 10. Uluslararası Spor Bilimleri Kongresi, Bolu.

Keser, A. (2005). Is Doyumu ve Yasam Doyumu İliskisi: Otomotiv Sektorunde Bir Uygulama. [Title in English: An Application in the Automotive Sector: Relationship Between Job Satisfaction and Life Satisfaction]. Calisma ve Toplum Dergisi, 4, 77-96.

Kilbas Koktas, S. (2004). Rekreasyon Bos Zamanı Degerlendirme. [Title in English: Recreation Leisure Assessment]. Ankara: Nobel Yayincilik.

Kocak, N. (2012). Yiyecek İcecek Hizmetleri Yonetimi. [Title in English: Food and Beverage Management]. Ankara: Detay Yayincilik.

Kodas, D., Kodas B., \& Arica, R. (2015, November). Yiyecek Icecek Calisanlarinin Serbest Zaman Duzeyleri ile Serbest Zamanda Algilanan Ozgurluklerinin Incelenmesi, 3. Rekreasyon Arastirmalari Kongresi Bildiri Kitabi, 1-13.

Kong, F., \& You, X. (2013). Loneliness and Self-Esteem as Mediators Between Social Support and Life Satisfaction in Late Adolescents, Social Indicators Research, 110, 271-279. https://doi.org/10.1007/s11205-011-9930-6 
Kozak, M. (2014). Bilimsel Arastirma: Tasarım, Yazım ve Yayım Teknikleri. [Title in English: Design, Writing and Publishing Techniques of Scientific Research]. Ankara: Detay Yayincilik.

Kucuk Kilic, S., Lakot, K., Gurbuz, B., \& Oncu, E. (2013, November). Rekreasyonel Tatmin ve Yasam Doyumu Arasindaki Iliskinin Incelenmesi, II. Rekreasyonel Arastırma Kongresi, Kusadas.

Kumartasli, M. (2010). Ilkogretim ikinci kademe ogrencilerinin beden egitimi dersine yonelik tutumlarının ve yasam doyum duzeylerinin incelenmesi. (Unpublished doctoral dissetation). Gazi Universitesi, Ankara.

Kwan, Y. K. (2008). Life Satisfaction and Family Structure among Adolescent in Hong Kong, Social Indicators Research, 86, 59-67. https://doi.org/10.1007/s11205-007-9092-8

Larsen, R. J., Diener, E., \& Emmons, R. A. (1985). An evaluation of subjective well-being measures, Social Indicators Research, 17, 1-17. https://doi.org/10.1007/BF00354108

Lemon, B. W., Bengtson, V. L., \& Peterson, J. A. (1972). An exploration of the Activity of Aging: Activity Types and Life Satisfaction Among in-movers to a Retirement Community, Journal of Gerontology, 27(4), 511-523. https://doi.org/10.1093/geronj/27.4.511

Lloyd, K. M., \& Auld, C. J. (2002). The Role of Leisure in Determining Quality of Life: Issues of Content and Measurement, Social Indicators Research, 57, 43-71. https://doi.org/10.1023/A:1013879518210

Lu, L., \& Hu, C. H. (2005). Personality, Leisure Experiences and Happiness, Journal of Happiness Studies, 6, 325-342. https://doi.org/10.1007/s10902-005-8628-3

Lu, L., \& Kao, S. F. (2009). Leisure Participation and Leisure Satisfaction: Moderating Effects of Personality Traits, Journal of Sport and Recreation Research, 3(3), 1-11.

Mieczkowski, Z. (1990). World Trend in Tourism and Recreation. New York: Peter Lang Publishing.

Nawjin, J., \& Veenhoven, R. (2011). The Effect of Leisure Activities on Life Satisfaction: The Importance of Holiday Trips, Springer Science, 39-53.

Neugarten, B. L., Havighurst, R. J., \& Tobin, S. S. (1961). The measurement of life satisfaction, Journal of Gerontology, 16, 134-143. https://doi.org/10.1093/geronj/16.2.134

O’Driscoll, M. P., Ilgen, D. R., \& Hildreth, K. (1992). Time Devoted to Job and Off-job Activities: Interrole Conflict and Affective Experiences, Journal of Applied Psychology, 77(3), 272-279. https://doi.org/10.1037/0021-9010.77.3.272

Orucu, E., Esenkal, F. (2005). Konaklama İsletmelerinde İsgoren Tatminini Etkileyen Faktorler (Bandırma ve Erdek Ornegi). [Title in English: The Factors Which Effec Job Satisfaction of Employees in Accomadation Organization (The Example of Bandirma and Erdek)]. Balıkesir Universitesi Sosyal Bilimler Enstitusu Dergisi, 8(14), 141-166. 
Pearson, Q. M. (1998). Job Satisfaction, Leisure Satisfaction and Psychological Health, The Career Development Quarterly, 46, 416-426. https://doi.org/10.1002/j.2161-0045.1998.tb00718.x

Pearson, Q. M. (2008). Role Overload, Job Satisfaction, Leisure Satisfaction and Psychological Health Among Employed Women, Journal of Counseling \& Development, 86, 57-63. https://doi.org/10.1002/j.1556-6678.2008.tb00626.x

Ragheb, M. G., \& Tate, R. L. (1993). Job Satisfaction, Leisure Satisfaction, and psychological health, The Career Development Quartely, 46, 416-426.

Riddick, C. C. (1986). Leisure Satisfaction Precursors, Journal of Leisure Research, 18, 259-265.

Rodriguez, A., Latkova, P., \& Sun, Y. Y. (2008). The Relationship Between Leisure and Life Satisfaction: Application of Activity and Need Theory, Social Indicators Research, 86(1), 163-175. https://doi.org/10.1007/s11205-007-9101-y

Ryan, R. M., \& Deci, E. L.(2000). Self-Determanination Theory and the Facilitation of Intrinsic motivation, Social Development, and Well-Being, Amerian Psyshologist, 55(1), 68-78. https://doi.org/10.1037/0003-066X.55.1.68

Seigenthaler, K. (1997). Health Benefits of Leisure, Research Update, Park and Recreations, 32(1), 24-31.

Seker, B. D., \& Zirhlioglu, G. (2009). Van Emniyet Mudurlugu Kadrosunda Calısan Polislerin Tukenmislik, Is Doyumu ve Yasam Doyumları Arasınaki iliskilerin Degerlendirilmesi. [Title in English: An Evaluation of the Relationshi Between Burn Out, Job Satisfaction and Life Satisfaction Among Police Officers in Van Police Department]. Turkish Journal of Police Studies, 11(4), 1-26.

Selcukoglu, Z. (2001). Arastirma Gorevlilerinde Tukenmislik Duzeyiyle Yalnizlik Duzeyi ve Yasam Doyumu Arasindaki Iliskinin Bazi Degiskenler Acisindan Degerlendirilmesi. (Unpublished master's thesis). Selcuk Universitesi, Konya.

Sener, A., Tersioglu, R. G., \& Karabulut, E. (2007). Life Satisfaction and Leisure Activities During Retirement of Men: A Turkish Sample, Aging \& Mental Health, 11(1), 30-36. https://doi.org/10.1080/13607860600736349

Sevil, T. (2012). Bos Zaman ve Rekreasyon Yonetimi. Serdar Kocaeksi (Ed.), [Title in English: Leisure and Recreation Management]. Anadolu Universitesi Acikogretim Yayinlari: Eskisehir.

Sop, S. A. (2014). Is Baskisi, Is-Serbest Zaman Catismasi, Meslek Memnuniyeti ve Yasam Doyumu Iliskisi Uzerine Bir Inceleme. [Title in English: An Investigation on the Relationship Between Job Strain, Work-to-Leisure Conflict, Occupational Satisfaction and Life Satisfaction]. Turizm Akademik Dergisi, 1(1), 1-14.

Stenseng, F., \& Phelps, J. (2013). Leisure and Life Satisfaction: The Role of Passion and Life 


\section{Il Macrothink}

Journal of Social Science Studies

ISSN 2329-9150

2017, Vol. 4, No. 1

Domain Outcomes, World Leisure Journal, 55(4), 320-332. https://doi.org/10.1080/04419057.2013.836558

Sumer, H. C., \& Knight, P. A. (2001). How do people with different atachment styles balance work and family? A personality perspevtive on work-family linkage, Journal of Personality and Social Psychology, 86(4), 653-663.

Tabachnick, J., \& Fidell, L. S. (2001). Using Multivariate Statistics. New York: Allyn and Bacon.

Tordkilsen, G. (2005). Leisure and Recreation Management. EveFN Spon, London, New York, Tokyo, Melburne, Madras.

Turkay, O., Kaya, M. C., \& Birer S. (2013). Yiyecek Icecek Calisanlarinin Mesleki Beklentilerinin Analizi: Istanbul Ornegi. 14. Ulusal Turizm Kongresi Bildiri Kitabl, 998-1015.

Urry, J. (2015). Mekanları Tüketmek. [Title in English: Consuming Places]. İstanbul: Ayrıntı Yayıncilik.

Wang, E. S., Chen, L. S., Lin, J. Y., \& Wang, M. C. (2008). The relationship between leisure satisfaction and life satisfaction of adolescents concerning online games, Adolescence, 43, 177-184.

Yerlisu Lapa, T. (2013). Life Satisfaction, Leisure Satisfaction and Perceived Freedom of Park Recreation Participants, Procedia- Social and Behavioral Sciences, 93, 1985-1993. https://doi.org/10.1016/j.sbspro.2013.10.153

Yetim, U. (1991). Kisisel Projelerin Organizasyon ve Oruntusu Acisindan Yasam Doyumu Izmir. (Unpublished doctoral dissetation). Ege Universitesi Sosyal Bilimler Enstitusu, İzmir.

Yigit, R., Dilmac, B., \& Deniz, M. E. (2011). Is ve Yasam Doyumu: Konya Emniyet Mudurlugu Alan Arastirmasi. [Title in English: Job and Life Satisfaction: A Survey of Konya Police Department]. Turkish Journal of Police Studies, 13(3), 1-18.

Yilmaz, E., \& Sunbul, A. M. (2009). Ogretmenlerin Yasam Doyumları ve Okullardaki Orgutsel Guven Duzeyi. [Title in English: The Organizational Confidence Level in School and Saturation of The Life of Teacher]. Journal of Qafgaz University, 26, 172-179.

Yilmaz, G., Keser, A., \& Yorgun S. (2010). Konaklama İsletmelerinde Calısan Sendika Uyelerinin Is ve Yasam Doyumunu Belirlemeye Yonelik Bir Alan Arastırması. [Title in English: The Impact of Job Satisfaction on Life Satisfaction and Intention to Leave Among Unionized Lodging Sector Employees]. PARADOKS, Journal of Economics, Sociology and Policy, 6(1), 87-107. 


\section{Copyright Disclaimer}

Copyright for this article is retained by the author(s), with first publication rights granted to the journal.

This is an open-access article distributed under the terms and conditions of the Creative Commons Attribution license (http://creativecommons.org/licenses/by/3.0/). 